International Journal of Applied Linguistics \& English Literature

ISSN 2200-3592 (Print), ISSN 2200-3452 (Online)

Vol. 1 No. 7; November 2012 [Special Issue on Applied Linguistics]

\title{
Conveying Communicative Intent: Moves and Metadiscourse in Abstract Writing
}

\author{
Chuah Ek Lon (corresponding author) \\ Faculty of Modern Language and Communication, Universiti Putra Malaysia \\ 43400 Serdang, Selangor, Malaysia \\ Tel: 012-5053429Ｅ-mail: sharonchuah3429@gmail.com \\ Helen Tan \\ Faculty of Modern Language and Communication, Universiti Putra Malaysia \\ 43400 Serdang, Selangor, Malaysia \\ Tel: 03-89468711Ｅ-mail: Helen@fbmk.upm.edu.my \\ Ain Nadzimah Abdullah \\ Faculty of Modern Language and Communication, Universiti Putra Malaysia \\ 43400 Serdang, Selangor, Malaysia \\ Tel: 03-89468788Ｅ-mail: ain@fbmk.upm.edu.my
}

Received: 19-10- 2012

Accepted: 22-11- 2012

Published: 25-11- 2012

doi:10.7575/ijalel.v.1n.7p.56

URL: http://dx.doi.org/10.7575/ijalel.v.1n.7p.56

\begin{abstract}
Abstracts form the first reading contact of extended discourse in pursuance of a meaningful engagement with a report. An abstract possesses distinct features drawn from a specific genre of academic writing that communicates its discourse intent to any academic or professional community. Among the discourse conventions is the use of a move pattern and metadiscourse elements which together, establishes logical connections with the reader. This paper investigates good communication practice in abstract writing, a significant preliminary that fronts a report. The effectiveness of an abstract specifically, can be tied to the realization of a peculiar move structure that is accompanied by a judicious choice of words and phrases that relates to and involves the reader both interactively and interactionally. A content analysis of the move structure and its underlying metadiscourse in 100 randomly selected abstracts gives petite indication of how students manage abstract writing in a technical report. The results will have a bearing on situating appropriate pedagogical approaches for the teaching of a salient feature in academic writing and will also inform students of related genre expectations towards abstract writing. It is a skill that they may not have sufficient contact with in their university writing experience, though, nonetheless, one that needs to be accomplished to fulfill communicative intent that serves both local and international purposes insofar as academic writing is concerned.
\end{abstract}

Keywords: abstract, metadiscourse, rhetorical moves and genre

\section{Introduction}

An abstract is a brief summary of the main components of a research project. It functions to save time in reading and gives a salient information about the article enabling the readers to decide as to whether they would want to further pursue a full reading.( Ali \& Sahawneh, 2011). Another aspect that Ventola (1994) emphasized about abstract is its function as an efficient organizing tool of information for the discourse community...Abstract is a specific genre in academic writing that involves metadiscourse which incorporates the use of appropriate linguistic realizations. In addition, abstract is guided by a series of moves which characterize the flow of the discourse. Several past investigations have examined rhetorical moves in research article abstracts (Stotesbury, 2003; Lores, 2004; Samraj, 2005; Pho, 2008; Ning, 2008; Ren \& Li, 2011). 


\section{International Journal of Applied Linguistics \& English Literature}

ISSN 2200-3592 (Print), ISSN 2200-3452 (Online)

Vol. 1 No. 7; November 2012 [Special Issue on Applied Linguistics]

This academic genre has been acknowledged as one that is a neglected field among discourse analysts (Swales, 1990:181) and to these present times it still warrants investigation as there is room for knowledge expansion especially from the point of student writing in terms of undergraduates' final year term papers. Literature search provided some update on related studies. For example, Suroso (2010) used final project reports from polytechnics to analyze rhetorical moves while Promsin (2006) examined the move structure of English engineering abstracts from research theses. In addition, Ali and Sahawneh (2011) had used English and Arabic $\mathrm{PhD}$ dissertations on linguistics to analyze the rhetorical moves in abstracts. This current research focuses on undergraduate writing to explore the genre of abstract writing, specifically that is related to hard sciences.

\subsection{Move Patterns}

Studies on move patterns had resorted to a variety of frameworks to unveil the rhetorical organization of the writing under study. The earliest ESP practitioner who pioneered rhetorical moves in 'introduction' section of research articles is Swales (1990). He proposes his famous CARS model (Create A Research Space) which posits three main moves that are shown as below:

- Move 1: Establishing a territory

- Move 2: Establishing a niche

- Move 3: Occupying the niche

Swales' CARS model is widely used among researchers who studied rhetorical moves in research article introductions (Fakhri, 2004; Kanoksilapatham, 2005; Samraj, 2005; Ozturk, 2007 and Hirano, 2009). The Introduction is the initial section that readers will have contact with in reading the main text. The purpose of an Introduction in research articles is different from that of the abstract which precedes the entire article as it is a condensation of the main points that are found in the whole article. Thus to analyze the abstract, other researchers have devised different frameworks to account for its rhetorical development. Among those made available is that of Santos's (1996) five-move pattern model. The functional model presents the moves according to salient questions asked as a reader delves into the understanding of the text. The framework and the questions are presented below:

Figure 1. Santos's (1996) Model of five moves pattern

\begin{tabular}{|c|c|c|}
\hline Move & Function/Description & Question asked \\
\hline $\begin{array}{l}\text { Move 1: Situating the research } \\
<\text { STR }>\end{array}$ & $\begin{array}{l}\text { Setting the scene for the current } \\
\text { research(topic generalization) }\end{array}$ & $\begin{array}{l}\text { What has been known about } \\
\text { the field/topic of research? }\end{array}$ \\
\hline $\begin{array}{l}\text { Move 2: Presenting the research } \\
<\text { PTR }>\end{array}$ & $\begin{array}{l}\text { Stating the purpose of the study, research } \\
\text { questions and/or hypotheses }\end{array}$ & What is the study about? \\
\hline $\begin{array}{l}\text { Move 3: Describing the } \\
\text { methodology }<\text { DTM }>\end{array}$ & $\begin{array}{l}\text { Describing the materials, subjects, variables, } \\
\text { procedures }\end{array}$ & How was the research done? \\
\hline $\begin{array}{l}\text { Move 4: Summarizing the findings } \\
\text { <STF> }\end{array}$ & Reporting the main findings of the study & What did the researcher find? \\
\hline $\begin{array}{l}\text { Move 5: Discussing the research } \\
<\text { DTR }>\end{array}$ & $\begin{array}{l}\text { Interpreting the results/findings and/or giving } \\
\text { recommendations, implications/applications } \\
\text { of study }\end{array}$ & $\begin{array}{l}\text { What do the results mean? } \\
\text { So what? }\end{array}$ \\
\hline
\end{tabular}

Santos (1996:485) emphasized that genre moves build up on one another, each contributing to a bigger picture in sequence. Similarly, Bhatia (2006) defines moves as 'rhetorical instruments that realize a sub-set of communicative purposes associated with a genre, and as such they are interpreted in the context of the communicative purposes of the genre in question' (pp 84-85). In Pho's (2008) study, Santos's (1996) model was used to compare abstract writing of 20 journals from the field of applied linguistics and 10 from educational technology. In the findings for applied linguistics abstracts, Pho (2008) identified obligatory and non obligatory moves. Pho classified Move $2(100 \%)$, Move $3(100 \%)$ and Move $4(100 \%)$ as 'obligatory moves' which were in line with Santos's (1996) results which also focused on applied linguistics abstracts, with slight variations in the

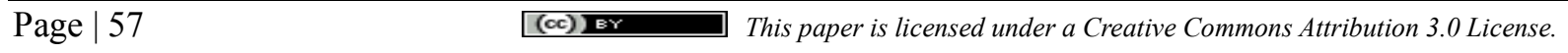




\section{International Journal of Applied Linguistics \& English Literature ISSN 2200-3592 (Print), ISSN 2200-3452 (Online)}

Vol. 1 No. 7; November 2012 [Special Issue on Applied Linguistics]

data - Move 2 (99\%), Move 3 (98\%) and Move 4 (80\%). In addition, Santos' (1996) framework was adopted by Tseng (2011) in examining the abstracts of 90 research articles in three applied linguistics journals. Tseng (2011) results also showed that Move $2(96 \%)$, Move 3(97\%) and Move 4(91\%) to be obligatory moves. It would appear that what is obligatory and non-obligatory could be an arbitrary judgment and the study of move patterns could still invite further exploration.

\subsection{Metadiscourse}

Together with the move patterns, there is a need to understand the accompanying linguistic realizations. One of them is metadiscourse which has intrigued many researchers. Metadiscourse as a term was first coined by Zellig Harris in 1959 to help understand language in use. The use of metadiscourse represents a writer's or speaker's attempt to guide a receiver's perception of a text. This concept was further developed by other researchers, such as, Williams (1981), Vande Kopple (1985) and Crismore (1989). Hyland (2005) later refined metadiscourse as an umbrella term to include an apparently heterogeneous array of cohesive and interpersonal features which help relate a text to its context. The use of metadiscourse is a major feature of communication in a range of genres in academic writing and Hyland sub-categorized metadiscourse into interactive and interactional categories to show more distinctions in communicative intent (see Fig. 2). The interactive function helps readers to move through the text while the interactional goes a step further in deeper reader involvement. Thus, textual functions are given interpretations and writers are able to account for their actions in text development. For many L1 writers, these functions are part of ingrained systems used in language expression, but for L2 writers much are learnt consciously in the form of guided instruction. Thus the research into writing and the accompanying results of this nature would have great relevance to the understanding of text organization and development. Hyland (2005) postulated that metadiscourse features increase the writer's presence in the text and make the writer more engaged with it. He further highlighted that metadiscourse signalled the writer's "friendly" attitude to the reader; and not least, they promote coherence and relate ideas clearly from one to another.

Figure 2. Hyland's Metadiscourse Model (2005)

\begin{tabular}{|l|l|l|}
\hline Category & Function & Examples \\
\hline Interactive & \multicolumn{1}{|c|}{ Help reader to guide through the text } & Resources \\
\hline Transition & Express relations between two clauses & In addition; but; thus; and \\
\hline Frame markers & Refer to discourse acts, sequences or stages & Finally; to conclude \\
\hline $\begin{array}{l}\text { Endophoric } \\
\text { markers }\end{array}$ & Refer to information in other parts of the text & $\begin{array}{l}\text { Noted above; see Fig; in } \\
\text { section 2 }\end{array}$ \\
\hline Evidentials & Refer to information from other texts & According to X; Z states \\
\hline Code glosses & Elaborate propositional meanings & Namely; e.g;; such as \\
\hline Interactional & Involve the reader in the text & Resources \\
\hline Hedges & Withhold commitment and open dialogue & Might; perhaps; possible \\
\hline Boosters & Emphasize certainty or close dialogue & In fact; definitely; it is clear \\
\hline $\begin{array}{l}\text { Attitude } \\
\text { markers }\end{array}$ & Express writer's attitude to proposition & $\begin{array}{l}\text { unfortunately; I agree; } \\
\text { surprisingly }\end{array}$ \\
\hline Self mentions & Explicit reference to author(s) & I; we; my; me; our \\
\hline $\begin{array}{l}\text { Engagement } \\
\text { markers }\end{array}$ & Explicitly build relationship with reader & Consider; note; you can see that \\
\hline
\end{tabular}

To date, only a few endeavours on the study of metadisourse features in L2 writings can be noted. Among them are Intaraparawat and Steffensen (1995) had analyzed the metadiscourse in persuasive essays written by 12 ESL university students. The evaluative that in abstracts was examined by Hyland and Tse (2005) who explored the frequencies, forms and functions of evaluative that in two corpora of 465 abstracts from published research articles, and masters' and doctoral dissertations written by L2 students. Burneikaite (2008) compared the use of metadiscourse in L1 (20 texts from 2 British Universities) and L2 (20 Lithuanian- English interlanguage corpus) 
International Journal of Applied Linguistics \& English Literature

ISSN 2200-3592 (Print), ISSN 2200-3452 (Online)

Vol. 1 No. 7; November 2012 [Special Issue on Applied Linguistics]

Master theses in Linguistics. In addition, Akbas (2012) compared and contrasted dissertation abstracts written by Native Speakers of Turkish (NST), Turkish Speakers of English (TSE) and Native Speakers of English (NSE) in the Social Sciences.

\subsection{Objectives}

This study situates rhetorical moves and metadiscourse features in undergraduate hard science abstract writing of final term papers. It seeks to answer the following questions;

\section{4 Research questions:}

1. What are the move patterns in undergraduate abstract writing?

2. What are the metadiscourse features that accompany the moves in the undergraduate abstract writing?

\section{Method}

The data contained 42,144 words from the corpus file of 100 abstracts. These are the compilation of undergraduates' final term papers from Computer and Communication System Engineering, UPM.This purposive sampling was from year 1999 until 2004. Researchers chose to examine 50 abstracts in year 1999 and subsequently 10 abstracts each for the following year were analyzed. In addition, a concordance tool MP2.2 is used to locate the features of the metadiscourse.

This present study uses Santos's five- move model (1996) which accounts for the crafting of a successful written abstract. In analyzing the features of metadiscourse, Hyland's model (2005) of interpersonal metadiscourse taxonomy is used (as shown in Figure 2). Metadiscourse realizations are initially manually tagged for further analysis according to the sub categories found in Hyland's model. The tagged words are then entered into the MP2.2 program for the identification of their occurrence in the texts. The benchmark of obligatory moves in this study is obtained after a comparison with that of Santos's (1996) results. (see figure 3). Eighty per cent (80\%) was established as the benchmark for an obligatory move.

Figure 3. Santos's (1996) results

\begin{tabular}{|c|l|l|}
\hline Moves & $\mathbf{N = 9 0}$ abstracts & Obligatory/Optional moves \\
\hline 1 & $43 \%$ & Optional \\
\hline 2 & $99 \%$ & Obligatory \\
\hline 3 & $98 \%$ & Obligatory \\
\hline 4 & $80 \%$ & Obligatory \\
\hline 5 & $53 \%$ & Optional \\
\hline
\end{tabular}

\section{Results and Discussion}

Pho's (2008) and Santos' (1996) studies revealed that Move 4 is obligatory and therefore would have a high incidence of occurrence. However, data obtained in this study shows Move 1 (STR), Move 2 (PTR), and Move 3 (DTM) to have the highest occurrences (see Table 1). Although Move 1 had a high incidence in this study, it did not reach the benchmark of $80 \%$ which is found in Santos's results and indicated as obligatory. This present study instead showed Move 2 as having the highest percentage (85\%) which answered the fundamental question of what the study was about. This took precedence over Move 1 which is concerned with Situating the Research. This finding though lower in percentage of occurrence, paralleled that of Santos's which showed an incidence of $99 \%$. In other words, students appeared to prefer a very direct approach in abstract writing in the sense that their primary goal is set in an introductory line that focused on informing the reader on what the research is all about. The most lengthy and detailed information is found in Move 3, Describing the Methodology. This had the second highest occurrences (83\%) which qualified it as an obligatory move. Move 4 dealt with summarizing the findings. In this study, Move 4 accounted for only $34 \%$ of the total moves. This was considered to be quite low and did not seem to be regarded as obligatory by student writers. This is in contrast with Santos's (1996) study which accounted for $80 \%$ and thus qualified as an obligatory move. Most of the abstracts in the present study omitted Move 5, Discussing the Research (17\%) which included the providing of implications of the study and recommendation for future research. From this result, we can conclude that students are limited in their writing skills and may have difficulty in pursuing this function meaningfully. Interpretation of the findings is generally 


\section{International Journal of Applied Linguistics \& English Literature}

ISSN 2200-3592 (Print), ISSN 2200-3452 (Online)

Vol. 1 No. 7; November 2012 [Special Issue on Applied Linguistics]

considered the hardest part in research management and reporting it poses a great challenge to students. There could be a few reasons to account for this limitation. One was their inability to synthesize meaningful discussion. This would mean that students have not been trained to write exponentially in this manner in an abstract. Two, the course instructors might not have insisted that students followed a particular pattern of abstract development to show the comprehensibility of information. As such, many abstracts terminated on Move 3.

Table 1. Rhetorical Moves in Computer and Communication System Engineering Final Year Project

\begin{tabular}{|c|c|c|c|c|c|}
\hline Moves & $\mathbf{1}$ & $\mathbf{2}$ & $\mathbf{3}$ & $\mathbf{4}$ & $\mathbf{5}$ \\
\hline $\begin{array}{c}\text { Total number of } \\
\text { moves (\%) }\end{array}$ & 72 & 85 & 83 & 34 & 17 \\
\hline
\end{tabular}

\subsection{Analysis of metadiscourse realizations}

Moving on to metadiscourse realizations (Table 2), the four most common features used in abstract writing. Three of the features, because, then and such as correspond to the subcategories of metadiscourse in Hyland's framework. However, the noun phrase, this project occurred most frequently but it was not possible to fit it into Hyland's model. As a result, the researchers resorted to the term topicalizer to indicate the function of this + noun to show how the writer has introduced a topic. This noun phrase occurred frequently in Move 2 in this study, and it was found to have 52 tokens used to introduce the aim of the paper. For example, This project is to find out the impact of using variable length packets or CIF on ATM in terms of overhead, Quality of service $(Q o S)$, throughput, delay and hardware requirements.

The noun phrase is also used quite frequently in Move 3 whenever a material or procedure is explained as in: This project was developed by using important notes and figures based in wiring telecommunications for building with a multimedia tool and image development tool. Next is the use of because as a transition marker (8 tokens), occurring highest in Move 1 and then in Move 3, (7 tokens). Students appeared to prefer the use of because to justify why a project is conducted or why a material is used. In linking ideas continuously, sequencer then is hardly utilized. Finally, elaborators such as occurred highest in Move 1 (13 tokens). In introducing a topic, such as is used to give examples of a variable mentioned. Then in Move 3, it occurred 8 times to give examples of material used in the project.

Table 2. Top four Linguistic Realizations in Computer and Communication System Engineering Final Year Abstracts

\begin{tabular}{|c|c|c|c|c|}
\hline & Topicalizer & Transition & Sequencer & Elaborator \\
\hline Move & This project & because & then & 13 \\
\hline M1 & 9 & 8 & 1 & 2 \\
\hline M2 & 52 & 0 & 7 & 8 \\
\hline M3 & 27 & 7 & 1 & 3 \\
\hline M5 & 9 & 1 & 10 & 28 \\
\hline
\end{tabular}

\subsection{Interactive Metadiscourse}

The discussion now focuses on the two main categories of interactive and interpersonal metadiscourse. In interactive metadiscourse, transition markers (see Table 3) are found in this study are because, but, however, since, on the other hand, besides, so and therefore. The word so occurred most frequently and it is most commonly found in Move 3. 
International Journal of Applied Linguistics \& English Literature

ISSN 2200-3592 (Print), ISSN 2200-3452 (Online)

Vol. 1 No. 7; November 2012 [Special Issue on Applied Linguistics]

Example: This technique is used to obtain a compressed image so that it can produced a good quality of pictures in high resolution $1024 x 768$ compared to low resolution $640 \times 480$.

We can see that the variety of transition markers used was not high and it showed students' weakness in using connective devices.

Table 3. Transitions

\begin{tabular}{|c|c|c|c|c|c|c|c|c|}
\hline Moves & Because & but & However & Since & $\begin{array}{c}\text { On the } \\
\text { other } \\
\text { hand }\end{array}$ & Besides & so & therefore \\
\hline M1 & 8 & 9 & 4 & 3 & 1 & 2 & 6 & 2 \\
\hline M2 & 0 & 4 & 0 & 1 & 0 & 1 & 3 & 1 \\
\hline M3 & 7 & 4 & 0 & 0 & 1 & 1 & 8 & 2 \\
\hline M4 & 1 & 0 & 0 & 0 & 0 & 0 & 1 & 0 \\
\hline M5 & 1 & 1 & 1 & 0 & 0 & 0 & 1 & 0 \\
\hline $\begin{array}{l}\text { Total no. } \\
\text { of tokens }\end{array}$ & 17 & 18 & 5 & 4 & 2 & 4 & 19 & 5 \\
\hline
\end{tabular}

In table 4, the phrase, such as, as an elaborator had the highest tokens (28) in Move 1, for example, The video transmission technology in particular is the hype nowadays with enormous demands for applications such as video conferencing, distance learning and video on demand. Then the word called (13) was found to be the next in rank followed closely by that is (12). Move 4 and move 5 were omitted quite frequently in the abstracts; therefore it was logical that few metadiscourse features were registered for these sections. The other elaborators, for example and namely are insignificantly used.

Table 4. Elaborators

\begin{tabular}{|c|c|c|c|c|c|c|}
\hline Moves & such as & that is & $\begin{array}{l}\text { for } \\
\text { example }\end{array}$ & $\begin{array}{l}\text { which } \\
\text { means }\end{array}$ & Called & namely \\
\hline M1 & 13 & 3 & 1 & 1 & 4 & 1 \\
\hline M2 & 2 & 2 & 1 & 0 & 2 & 1 \\
\hline M3 & 8 & 6 & 0 & 0 & 7 & 2 \\
\hline M4 & 2 & 0 & 0 & 0 & 0 & 0 \\
\hline M5 & 3 & 1 & 0 & 0 & 0 & 0 \\
\hline Total no. of tokens & 28 & 12 & 2 & 0 & 13 & 4 \\
\hline
\end{tabular}

As for frame markers, after then (10 tokens), was first ( 7 tokens), the data showed that the use of frame markers is quite low. First was followed by second ( 6 tokens), and then after ( 5 tokens). In table 5, we can see that frame markers occurred mostly in Move 3 where the procedure in methodology is explained.

Example: The image is then pre-processed and the height is calculated using stereo imaging method.

Table 5. Frame markers

\begin{tabular}{|c|c|c|c|l|}
\hline Moves & then & first & second & after \\
\hline M1 & 1 & 4 & 2 & 1 \\
\hline M2 & 1 & 0 & 0 & 0 \\
\hline M3 & 7 & 3 & 4 & 4 \\
\hline M4 & 1 & 0 & 0 & 0 \\
\hline M5 & 0 & 0 & 0 & 0 \\
\hline $\begin{array}{c}\text { Total no. } \\
\text { of tokens }\end{array}$ & 10 & 7 & 6 & 5 \\
\hline
\end{tabular}




\section{International Journal of Applied Linguistics \& English Literature}

ISSN 2200-3592 (Print), ISSN 2200-3452 (Online)

Vol. 1 No. 7; November 2012 [Special Issue on Applied Linguistics]

Endophoric markers were not used at all. Perhaps these expressions were less relevant as a linguistic choice in abstract writing. It was almost exactly the same with evidentials where only according (1 token) was captured. Example: According to the specified feedback rate, the proposed MPEG coder will convert the feedback rate into a factor in order to change the quantizing scale in video encoding for changing the video sending rate dynamically.

\subsection{Interactional Metadiscourse}

Under interactional metadiscourse, the hedging device, generally, occurred the most (5 tokens). For example, Generally, this system has two main parts,i.e the software and the hardware part. Other forms of hedges like, around, mostly, mainly, etc. were registered as 5 tokens and below.

Table 6. Hedges

\begin{tabular}{|c|c|c|c|c|c|c|c|}
\hline Moves & almost & generally & around & mostly & mainly & should & might \\
\hline M1 & 1 & 1 & 3 & 0 & 1 & 2 & 1 \\
\hline M2 & 0 & 2 & 1 & 0 & 3 & 0 & 0 \\
\hline M3 & 1 & 1 & 0 & 2 & 0 & 1 & 1 \\
\hline M4 & 0 & 0 & 0 & 0 & 0 & 0 & 2 \\
\hline M5 & 0 & 1 & 0 & 0 & 0 & 1 & 0 \\
\hline $\begin{array}{c}\text { Total no. } \\
\text { of tokens }\end{array}$ & 2 & 5 & 4 & 2 & 4 & 4 & 4 \\
\hline
\end{tabular}

Boosters are hardly used in abstract writing (table 7) with must occurring only 4 times as the most used. An example of its use is: Users must be connected to each other and the outside world to remain competitive in today's information driven business and educational environment. Perhaps undergraduate students are not grounded in such expressions to show this function of making a claim or marking an assertion.

Table 7. Booster

\begin{tabular}{|c|c|c|c|c|c|}
\hline Moves & must & found & realize & shows & shown \\
\hline M1 & 2 & 0 & 0 & 0 & 0 \\
\hline M2 & 0 & 0 & 0 & 0 & 1 \\
\hline M3 & 2 & 1 & 0 & 0 & 0 \\
\hline M4 & 0 & 1 & 0 & 1 & 0 \\
\hline M5 & 0 & 0 & 0 & 0 & 0 \\
\hline $\begin{array}{c}\text { Total no. of } \\
\text { tokens }\end{array}$ & 4 & 2 & 0 & 1 & 1 \\
\hline
\end{tabular}

In terms of the highest occurrence in attitude markers the expression, important (see table 8), registered 15 tokens. Students seemed to emphasize their research with the word important.

Example: Water volume is important because it is useful in industrial instrumentation such as process control and cost accounting.

This repetition indicates an important lexical choice in instantiation of a claim that shows an attitude of the writer. Then, the word even occurred 9 tokens and can be found more in Move 1. 
International Journal of Applied Linguistics \& English Literature

ISSN 2200-3592 (Print), ISSN 2200-3452 (Online)

Vol. 1 No. 7; November 2012 [Special Issue on Applied Linguistics]

Table 8. Attitude markers

\begin{tabular}{|c|c|c|c|c|c|c|}
\hline Moves & important & even & expected & interesting & essential & correctly \\
\hline M1 & 11 & 5 & 2 & 2 & 2 & 1 \\
\hline M2 & 2 & 0 & 0 & 0 & 1 & 0 \\
\hline M3 & 2 & 1 & 1 & 1 & 1 & 0 \\
\hline M4 & 0 & 2 & 2 & 0 & 0 & 0 \\
\hline $\begin{array}{c}\text { Total no. of } \\
\text { tokens }\end{array}$ & 15 & 9 & 6 & 3 & 4 & 0 \\
\hline
\end{tabular}

The preferred form of self mention is the personal pronoun we (17 tokens) in Move 1 and our ( 8 tokens, mostly in move 1 as well) compared to the possessive case of mine and my which had totally zero occurrences. The plural we as a self-mention indicates that some students had consciously chosen an inclusive discourse marker that appears to include the reader or the project supervisor in forwarding an argument as in: Today, we see more and more merchants interested in offering their goods and service to the public interactively using Web technology.

Table 9. Self mentions

\begin{tabular}{|l|c|c|c|c|c|}
\hline Moves & $\begin{array}{c}\text { we } \\
\text { (engagement } \\
\text { marker) }\end{array}$ & $\begin{array}{c}\text { our } \\
\text { (engagement } \\
\text { marker) }\end{array}$ & my & $\begin{array}{c}\text { us } \\
\text { (engagement } \\
\text { marker) }\end{array}$ & mine \\
\hline M1 & 17 & 7 & 0 & 1 & 0 \\
\hline M2 & 3 & 0 & 0 & 0 & 0 \\
\hline M3 & 0 & 0 & 0 & 0 & 0 \\
\hline M4 & 0 & 1 & 0 & 1 & 0 \\
\hline M5 & 3 & 0 & 0 & 0 & 0 \\
\hline Total no. of tokens & 23 & 8 & 0 & 2 & 0 \\
\hline
\end{tabular}

As for engagement markers (table 10), your occurred 6 times in Move 1. An example is: These viruses come on to your computer unnoticeably without even asking permission from you, until something goes wrong.

We can conclude that we, our, us can also be regarded as engagement markers. Engaging the reader in this respect is not a very highly preferred mode in abstract writing.

Table 10. Engagement markers

\begin{tabular}{|c|c|c|c|c|c|c|}
\hline Moves & your & consider & define & observe & have to & compare \\
\hline M1 & 6 & 1 & 1 & 0 & 3 & 0 \\
\hline M2 & 0 & 0 & 1 & 0 & 0 & 0 \\
\hline M3 & 0 & 0 & 1 & 0 & 1 & 0 \\
\hline M4 & 0 & 0 & 0 & 0 & 0 & 0 \\
\hline M5 & 0 & 0 & 0 & 0 & 0 & 0 \\
\hline Total of tokens & 6 & 1 & 3 & 0 & 4 & 0 \\
\hline
\end{tabular}

\section{Conclusion}

In summary, not all moves are used in sequence from Move 1 to Move 5. The use of the standard 5 moves was an exception rather than the rule in student abstract writings. Omission of Move 4 and 5 in most of the abstracts 
International Journal of Applied Linguistics \& English Literature

ISSN 2200-3592 (Print), ISSN 2200-3452 (Online)

Vol. 1 No. 7; November 2012 [Special Issue on Applied Linguistics]

was evidence of student writers' lack of awareness or training that the essence of abstract writing rests on the moves that show summary of major findings and discussion.

Accompanying the moves used were the metadiscourse features which were not too varied in abstract writing. They contributed, however, to essential development of discourse flow and development of ideas. For example, it was found that students mainly used topicalizers to identify the objective of the study. These metadiscourse features can be related to moves to explore functional meaning at specific localities in topical development. Students seem to have limited capability in such language use.

Abstract writing as a specific genre, serves an important function in a report. Students have to learn to develop ideas, synthesize, showcase, and give information succinctly within a limited space, and this can be a formidable challenge. As we can see at table 1, the results showed that Move 4 (STF) and Move 5 (DTR) are frequently omitted revealing that the abstracts are lacking in text organization. Findings of the study also generally point to the inability of students to handle the developmental patterns and the accompanying metadiscourse in abstract writing. This leads to pedagogical implications for ESP classrooms. Making Santos's model explicit can serve as a guideline in abstract writing especially for novice writers. There is a need to raise awareness of students and teachers on the importance of using the 5 moves in abstract writing. The data could be used as authentic teaching materials to showcase abstract writing problems of students in classroom instruction. In addition, the data can be used as informed input in the structuring of a writing program for academic purposes. The 'preface' function of an abstract has to be mastered to create the important first favourable impression, and give the necessary holistic impact on the reader in connecting to discourse that is organized and informative.

\section{References}

Akbas, E. (2012). Exploring metadiscourse in master's dissertation abstracts: Cultural and linguistic variations across postgraduate writers. International Journal of Applied Linguistics \& English Literature, 1(1), 12-26.

Al-Ali, M.N., \& Sahawneh, Y.B. (2011). Rhetorical and textual organization of English and Arabic PhD dissertation abstracts in linguistics. SKY Journals of Linguistics, 24, 7-39.

Bhatia, V.K. (2006). Analyzing Genre: Some Conceptual Issues. In M. Hewings (Ed.) Academic Writing in Context: Implications and Applications (pp.79-92). Birmingham: University of Birmingham Press.

Burneikate, N. (2008). Metadiscourse in linguistics master's theses in English L1 and L2. Kalbotyra, 59(3), 38-47.

Crismore, A. (1989). Talking with readers: Metadiscourse as rhetorical act. New York: Peter Lang.

Fahkri. A. (2004). Rhetorical properties of Arabic research article introductions. Journal of Pragmatics, 36, 1119-1138.

Hirano, E. (2009). Research articles introduction in English for specific purposes: A comparison between Brazilian Portuguese and English. English for Specific Purposes, 28, 240-250.

Hyland, K. (2005). Metadiscourse: Exploring interaction in writing. New York: Continuum.

Hyland, K., \& Tse, P. (2005). Hooking the reader: A corpus study of evaluative that in abstracts. English for Specific Purposes, 24, 123-139.

Intaraparawat, S., \& Steffensen, M. S. (1995). The use of metadiscourse in good and poor ESL essays. Journal of Second Language Writing, 4(3), 253-272.

Kanoksilapatham, B. (2005). Rhetorical structure of biochemistry research articles. English for Specific Purposes, 24, 269-292.

Lores, R.(2004). On RA abstracts: From rhetorical structure to thematic organization. English for Specific Purposes, 23, 280-302.

Ning, Z,Y. (2008). A genre-based analysis of English research article abstracts and the linguistic feature of personal pronouns for financial economics. US-China Education Review, 5(7), 62-65.

Ozturk, I. (2007). The textual organisation of research article introduction in Applied Linguistics: Variability within a single discipline. English for Specific Purposes, 26,25-38.

Pho, P.D. (2008). Research article in Applied Linguistics and Educational Technology: A study of linguistic realizations of rhetorical structure and authorial stance. Discourse Studies, 10 (2),231-250. 


\section{International Journal of Applied Linguistics \& English Literature}

ISSN 2200-3592 (Print), ISSN 2200-3452 (Online)

Vol. 1 No. 7; November 2012 [Special Issue on Applied Linguistics]

Promsin, P. (2006). An analysis of moves and modality in English engineering abstracts. NIDA Language and Communication Journal. 43-61.

Ren, H.W., \& Li, Y.Y.(2011). A comparison study on the rhetorical moves of abstracts in published research articles and master's foreign-languages theses. English Language Teaching, 4(1), 162-166.

Samraj, B. (2005). An exploration of a genre set: Research article abstracts and introductions in two disciplines. English for Specific Purposes, 24,141-156.

Santos, M.B.D. (1996). The textual organization of research paper abstracts in Applied Linguistics. Text, 16, 481-499.

Stotesbury, H. (2003). Evaluation in research article abstracts in the narrative and hard sciences. Journal of English for Academic Purposes, 2, 327-342.

Suroso, I. (2010). Moves in the English abstracts of students' final project reports. Ragam Jurnal Pengembangan Humaniora. 10 (1), 17- 25.

Swales, J. (1990). Genre analysis. Cambridge: Cambridge University Press.

Tseng, F.P. (2011). Analyses of move structure and verb tense of research article abstracts in Applied Linguistics journals. International Journal of English Linguistics, 1(2), 27-39.

Vande Kopple, W. (1985). Some exploratory discourse on metadiscourse. College Composition and Communication, 36, 82-93.

Ventola, E. (1994). Abstracts as an object of linguistic study. In S. Cmejrkova, F. Danes \& E. Havlova (Eds.) Writing vs Speaking: Language, Text, Discourse, Communication. Proceedings of the Conference. Held at the Czech Language Institute of the Academy of Sciences of the Czech Republic, Prague, 14-16 October 1992 (pp. 333-52). Tubingen: G. Narr.

William, J. (1981). Style: Ten lessons in clarity and grace. Boston: Scott Foresman. 